\title{
Effects of Brand Quality, Brand Prestige on Brand Purchase Intention of Mobile Phone Brands: Empirical Assessment from Kenya
}

\author{
Josphine Chepchirchir ${ }^{1}$, Mark Leting ${ }^{2}$ \\ ${ }^{1}$ Department of Marketing and Logistics, Moi University, Kenya \\ ${ }^{2}$ Kibabii university colleges, Kenya \\ ${ }^{1}$ Email (corresponding author): joschirie@gmail.com
}

\begin{abstract}
This study aims to empirically examine the relationship between Brand quality, brand prestige and brand purchase intention of mobile phone brands in Kenya. A survey was used to collect data from a sample of 322 respondents. Data were analyzed by employing correlation, Analysis of Variance (ANOVA) and multiple regression analysis. The results revealed that brand quality and brand prestige are positively associated with consumer brand purchase intention. The generalizability of the findings is limited as the study focuses only on Kenya. Based on the findings, companies involved in branding of mobile phones should focus on improving the usefulness of the brand quality and prestige. The study made a contribution in terms of allowing us to understand the factors that can contribute to the adoption of mobile phone brands.
\end{abstract}

Keywords: Perceived brand quality, Brand prestige, Brand purchase intention, Kenya

\section{Introduction}

Brands are no longer supportive functions of marketing; rather, brands are the essence of marketing (Salzer-Morling and Strannegard, 2004), providing stakeholders with greater financial rewards than unbranded products (Pahud de Mortanges and van Reil, 2003).Brand is part of operational and emotional characteristics that customer attributes to products and services and is a supporter of customers in decision making and purchase intention (Madani, 2010). On the basis of perceptions about a brand's position, consumers may rank order competing brands from low to high, and assess brands as having different levels of prestige (McGoldrick, 1984; O'Cass and McEwan, 2004). Essentially, consumers may perceive status as important to gain recognition (Goldsmith, Clark and Zboja, 2007), or because the status of the brand is associated with using better materials, and/or having a lower variability of quality (McGoldrick, 1984). Understanding this process that creating perceived value leads to customer's purchase intention, is an important issue in contemporary marketing because it establishes a connection between companies' marketing functions and financial functions (Luni, Neda., 2010). Though, brand-aroused feelings aren't always good, they can vary in direction and vary in intensity from mild to strong (Edell and Burke, 1987; Escalas, Moore and Briton, 2004). Feelings in relation to a brand may be aroused directly (O'Cass and Lim, 2001; O'Cass and Grace, 2003) or indirectly through advertising or product placement (e.g. Batra and Holbrook, 1990; Escalas et al., 2004; Geuens, 1998). In the mobile industry in Kenya like many industries, severe concentration of selected brand is evident, which is an indicator of triumph of companies with the right brand value and disappearance of those without such strategies.

\section{Literature Review}

\subsection{Purchase Intention}

Purchase intention represents the possibility that consumers will plan or be willing to purchase a certain product or service in the future. An increase in purchase intention means an increase in the possibility of purchasing (Dodds, 1991; Schiffman and Kanuk, 2007). Doing purchase intention for a specific brand requires assessment of all brands available in market (Teng, Laroche and Huihuang, 2007). When consumers have a positive purchase intention, this 
forms a positive brand commitment which propels consumers to take an actual purchase action (Fishbein and Ajzen, 1975; Schiffman and Kanuk, 2007). To do so consumers should obey their practices in the past for the products in particular type (e.g. brand loyalty or habitual buying) in formation of the decision for the purchase of the product (Terrell, 2002). From the above definitions and discussions, the definition of purchase intention in this study follows the definition of Teng, Laroche and Huihuang, 2007.

\subsection{Factors Affecting the Brand Purchase Intention}

Past studies included frameworks and models to clarify the effects of perceive brand value. Most of them are based on the theories such as TPB (Ajzen, 1991) and Consumer Utility theory. TPB was extended from theory of reasonated action (TRA). Besides, technological factors, TPB also focused on social and individual factors (Khalifa and Shen, 2008). The theory of planned behavior stated that behavioral intention to perform an activity is determined by attitude, perceived behavioral control, and subjective norm (Ajzen, 1991; Fusilier and Durlabhji, 2005). Attitude is defined as a person's feelings about performing behavior. Perceived behavioral control is defined as "the perception of how easy or difficult it is to perform a behavior" (Fusilier and Durlabhji, 2005,) and subjective norm is defined as "one's beliefs about whether significant others think that one should engage in the activity" (Fusilier and Durlabhji, 2005). Utility theory in consumer economics assumes that consumers will think about the choices in order to maximize the utility rationally. Consumer attains decisions account for perceived risks and consequences under conditions of uncertainty in purchase decision making (Baker, 2001). It broadly captures psychological concerns that people have but does not consider cost and benefit in terms of consumer attitudes. Utility theory in psychology states that consumer choice behaviour is predicted whether it is rational or irrational (Fishburn, 1968).

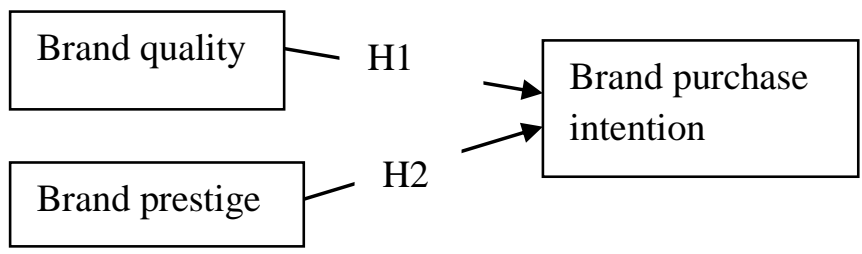

Figure 1: The Conceptual Model

\subsubsection{Brand Quality}

Brand quality is defined as the recognition of product quality, which has an influence on consumer purchasing behavior. The effect of brand quality on brand purchase intention has been validated in many existing studies (Bartikowski et al.,2010) suggested that higher quality perceptions lead to increased profits due to premium prices and in the long run, to effective business growth, involving both market expansion and market share gains. Therefore, we propose that;

$H_{l}$. Brand Quality has a positive effect on consumer brand purchase intention in Kenya.

\subsubsection{Brand Prestige}

Brand Prestige is an expression of evaluative judgment that conveys high or low status, which depends on life experiences, knowledge and an awareness of competing brands (O'Shaughnessy and O'Shaughnessy, 2002). An inherent, unique know-how, which concerns a specific attribute or the overall quality and performance of the product, is the key criterion for a brand to be judged prestigious (Baek, 2010). Brand prestige -meaning emotional or logical perceptions of consumers concerning a particular brand especially when it is difficult to differentiate products based on tangible qualitative characteristics- plays an important role in customer's shopping behavior. It is because of this that brand value is considered an important asset, and powerful brands increase customer's trust in purchasing product and service and enables them to perceive and imagine intangible factors well. According to brand management, brand value can result from perceived value by customer to a large extent and finally impacts on customer's preference and their purchasing (Luni, Neda., 2010). Therefore, we propose that;

$H_{1}$. Brand Prestige has a positive effect on consumer brand purchase intention in Kenya. 


\section{Methodology}

\subsection{Sampling and Data Collection}

The instrument was developed for testing the hypothesis. In order to ensure the content validity of the scale, it is advised to largely adapt the items for each construct from prior researches (Luarn and Lin, 2005). Hence, in this study, 6 items for brand purchase intention, 7 items for brand quality and 6 items for brand prestige from the prior empirical studies, and are modified to fit context of brand purchase intention. Table 3.0 shows the sources of where the questions were adapted from. The target populations of this study are continuing post-graduate students who are mobile phone brand sensitive. The reason why these users were considered was due to the fact that they were likely to adopt brand purchase intention in the future.

Table 3: Constructs and their Sources

\begin{tabular}{lll}
\hline Constructs & Number of Items & Sources \\
\hline Brand purchase intention & 6 & Paurav,2009 \\
Brand quality & 7 & Franz R Esch and Tobias Langer, \\
& & $\begin{array}{l}\text { Bernd H. Schmitt, Patrick Geus } \\
(2006) .\end{array}$ \\
Brand prestige & 6 & Franz R Esch and Tobias Langer, \\
& & $\begin{array}{l}\text { Bernd H. Schmitt, Patrick Geus } \\
(2006) .\end{array}$ \\
\hline
\end{tabular}

Source: Research Data, 2014

The questionnaires for this study were distributed to continuing post-graduate students of Masinde Muliro Univesity of Science and Technology in Kenya. A total of 322 hardcopy questionnaires were distributed among continuing post graduate students, 231 questionnaires were got back fully filled, which gave a response rate of $71.7 \%$, which is a sufficient sample size for analysis. Twenty of the questionnaires were incomplete and considered unsuitable in the study. Statements that were negatively stated were reversed coded during analysis. As cited in Hinkin (1995), an ideal sample size should have an item to response ratios ranged from as low as 1:4 to as high as 1:10 for each set of scales to be factor analyzed.

\subsection{Variable Measurement}

\subsubsection{Independent variables}

A total of 13 questions were developed to capture brand quality. Each question was measured by five-point Likert Scale. For instance, "1" denoted as strongly disagreed, " 2 " denoted as disagree, " 3 " denoted as neutral, " 4 " denoted as agree and " 5 " denoted as strongly agree.

\subsubsection{Dependent Variable: Brand Purchase Intention}

The measurements for brand purchase intention were measured using items adapted from the original Paurav, (2009). The brand purchase intention item was measured using five-point Likert scale where 1 - strongly disagree, 2 disagree, 3 - neutral, 4 - agree and 5 - strongly agree. The reliability coefficient for the scale was 0.879 .

\section{Data Analyses and Results}

The demographic profile of the respondents is presented in Table 4.0, which includes gender, age group, highest level of academic qualification and mobile phone brand. The total sample for the study consists of 231 . The gender distribution of the respondents is 47.2 per cent males and 52.8 per cent females. The results also indicated that the samples had age predominantly between 36 and 40 years, which is 34.6 per cent. The majority of the respondents had Doctor of Philosophy (D.Phi.) with 49.3 per cent, masters had 30.3 per cent and degree had 20.3 per cent. Most of the respondents' intend to use Samsung which had 43.3 per cent, followed by Nokia with 30.3 per cent. 
Table 4: Demographic Characteristic of the Respondents

\begin{tabular}{|c|c|c|c|}
\hline Variables & & Frequency & $\overline{\text { Percentages }}$ \\
\hline \multirow[t]{3}{*}{ Gender } & Male & 109 & 47.2 \\
\hline & Female & 122 & 52.8 \\
\hline & Total & 231 & 100 \\
\hline \multirow[t]{6}{*}{ Age } & $21-25$ & 26 & 11.0 \\
\hline & $26-30$ & 37 & 16.0 \\
\hline & $31-35$ & 73 & 31.6 \\
\hline & $36-40$ & 80 & 34.6 \\
\hline & 41 and above & 15 & 6.8 \\
\hline & Total & 231 & 100 \\
\hline \multirow[t]{4}{*}{ Highest level of education } & D.phil & 114 & 49.3 \\
\hline & Masters & 70 & 30.3 \\
\hline & Degree & 47 & 20.3 \\
\hline & Total & 231 & 100 \\
\hline \multirow[t]{6}{*}{ Mobile phone brand } & Nokia & 70 & 30.3 \\
\hline & Samsung & 100 & 43.3 \\
\hline & LG & 10 & 4.3 \\
\hline & Alcatel & 22 & 9.5 \\
\hline & Any other & 12.6 & 12.6 \\
\hline & Total & 231 & 100 \\
\hline
\end{tabular}

\section{Source: Research Data, 2014}

\subsection{Scale Reliability and Factor Analysis}

Cronbach's Coefficient $(\alpha)$ was used to measure the reliability of the scales. The reliability coefficients $(\alpha)$ of each independent variable are as follows: Brand quality (0.700) and Brand Prestige (0.780). The reliability coefficients of all the independent variables are above 0.700, which concurs with the suggestion made by Nunnally (1978). Construct validity measures "the degree to which a scale measures what it intends to measure" (Garver and Mentzer, 1999) and it is assessed by factor analysis in this study. In order to assess the construct validity, 13 items are examined by principal components extraction with varimax rotation. The Kaiser- Meyer -Olkin (KMO) has a measure of 0.867, which is above the threshold of 0.5 (Field, 2005). The Barlett's test is significant in this study with $\chi^{2}=2,170.244(p$ value $<0.000$ ).

Table 4.1 and 4.2 show the factor loading for each item, and they are sorted by size. Any item that fails to meet the criteria of having a factor loading value of greater than 0.5 will be dropped from the study (Liao et al., 2007).Table 4.1 shows that 13 items are sorted and clustered into two components: Factor 1 (Brand Quality and Factor 2 (Brand Prestige). Table 4.2 shows that the dependent variables are clustered into 1 factor (Brand Purchase Intention). The eigenvalues for each factor is greater than $1.0(2.348,1.120,2.884)$, which implies that each factor can explain more variance than a single variable. Based on above results, the construct validity is established.

\subsection{Correlation Analysis}

Since a single construct in the questionnaire was measured by multiple items, the average score of the multi-items for a construct was computed and used in further analysis such as correlation analysis and multiple regression analysis (Wang and Benbasat, 2007). Pearson correlation analysis was conducted to examine the relationship between the variables (Wong and Hiew, 2005; Jahangir and Begum, 2008). However, according to Field (2005), correlation coefficient should not go beyond 0.8 to avoid multicollinearity. Since the highest correlation coefficient is 0.368 which is less than 0.8 , there is no multicollinearity problem in this study all the independent variables had a positive correlation with the dependent variable.

Brand quality with highest a correlation of $(r=0.343 \mathrm{p}<0.05)$ and then brand prestige with a correlation of $(r=0.302 \mathrm{p}<$ 0.05). This indicates that all the variables are statistically significant at the $99 \%$ confidence interval level 2 -tailed. This shows that all the variables under consideration have a positive effect on the dependent variable. 
Table 4.1: Factor Analysis

\begin{tabular}{|c|c|c|c|c|}
\hline Variables & Scale Items & $\begin{array}{l}\text { Factor } \\
\text { loading }\end{array}$ & $\begin{array}{l}\text { Eigen } \\
\text { values }\end{array}$ & $\begin{array}{l}\text { Percentage of } \\
\text { variance }\end{array}$ \\
\hline \multirow[t]{7}{*}{ Brand quality } & The quality of this brand is extremely high & 0.725 & 2.348 & 33.536 \\
\hline & The functionality of this brand is very high & 0.674 & 1.120 & 15.998 \\
\hline & This brand is consistent in the quality it offers & 0.662 & & \\
\hline & The performance of this brand is very high & 0.653 & & \\
\hline & The durability of this brand is very high & 0.801 & & \\
\hline & The reliability of this brand is very high & 0.653 & & \\
\hline & This brand has an acceptable standard of quality & 0.645 & & \\
\hline \multirow[t]{6}{*}{$\begin{array}{l}\text { Brand } \\
\text { prestige }\end{array}$} & This is a very prestigious brand & 0.791 & 2.884 & 48.062 \\
\hline & This is not a very prestigious brand & 0.643 & & \\
\hline & To me, this brand represents what is all to me & 0.710 & & \\
\hline & $\begin{array}{l}\text { This brand does not represent what is all about } \\
\text { me }\end{array}$ & 0.625 & & \\
\hline & To me, this mobile phone brand is very good & 0.754 & & \\
\hline & This brand is not a very good symbol & 0.617 & & \\
\hline
\end{tabular}

Source: Research Data, 2014

Table 4.2: Factor Analysis

\begin{tabular}{lllll}
\hline Variables & Scale items & $\begin{array}{l}\text { Factor } \\
\text { Loading }\end{array}$ & $\begin{array}{l}\text { Eigen } \\
\text { values }\end{array}$ & $\begin{array}{l}\text { Percentage of } \\
\text { variance }\end{array}$ \\
\hline $\begin{array}{l}\text { Brand Purchase } \\
\text { intention }\end{array}$ & & & & \\
& $\begin{array}{l}\text { I feel good about my decision to purchase this } \\
\text { mobile phone brand }\end{array}$ & 0.979 & 2.706 & 67.653 \\
& & & \\
& $\begin{array}{l}\text { I will positively recommend this mobile } \\
\text { phone brand to other people }\end{array}$ & 0.948 & & 29007 \\
& $\begin{array}{l}\text { I intent to purchase this phone if the cost is } \\
\text { reasonable for me }\end{array}$ & 0.979 & & \\
\hline
\end{tabular}


Table 4.3: Correlation

\begin{tabular}{llll}
\hline Items & Brand purchase intention & Brand quality & Brand prestige \\
\hline Brand Purchase Intention & 1 & & \\
Brand quality & $.343^{* *}$ & 1 & \\
Brand Prestige & $.302^{* * *}$ & $.354^{* * *}$ & 1 \\
\hline
\end{tabular}

**. Correlation is significant at the 0.01 level (2-tailed).

\subsection{Multiple Regression Analysis}

Multiple regression analysis was employed to test the hypotheses. Multiple regression analysis is applied to analyze the relationship between a single dependent variable and several independent variables (Hair et al., 2005).

Table 4.4: Test of individual Regression Coefficients

\begin{tabular}{lccccc}
\hline Predictor variables & $\beta$ & $t$-value & Sig. & Tolerance & VIF \\
\hline (Constant) & 0.806 & 1.692 & 0.092 & & \\
Brand quality & 0.215 & 3.301 & 0.001 & 0.836 & 1.196 \\
Brand prestige & 0.135 & 2.004 & 0.046 & 0.786 & 1.272 \\
Overall model $\boldsymbol{F}=15.671 ; \boldsymbol{P}<\mathbf{0 . 0 0 0} ; \boldsymbol{R}^{2}=\mathbf{0 . 2 2 3}$; adjusted $\boldsymbol{R}^{2}=\mathbf{0 . 2 0 7}$ & & & & & \\
\hline
\end{tabular}

In order to test for multicollinearity among the predictor variables, variance-inflation factor (VIF) and tolerance were applied. The multicollinearity statistics showed that the tolerance indicators for brand quality and brand prestige are all greater than 0.2, and their VIF values are less than 10. The result indicates that no multicollinearity problem has occurred in this study (Neter et al., 1996; Ott and Longnecker, 2001). The F-statistics produced $(\mathrm{F}=15.671)$, thus confirming the fitness for the model. Therefore, there is a statistically significant relationship between the brand perceive value factors and brand purchase intention. The coefficient of determination $\mathrm{R}^{2}$ was 22.3 per cent. Thus, the brands perceive value factors can significantly account for 22.3 per cent in the brand purchase intention. The results indicated that brand quality was positive and significantly associated with brand purchase intention $(\beta=0.215, \mathrm{P}<.005)$, supporting $\mathrm{H}_{1}$. The relationship between brand prestige and brand purchase intention was was positively and significant $(\beta=0.135, \mathrm{P}<.005)$, supporting $\mathrm{H}_{2}$.

\section{Discussion}

Brand quality was found to be the most significant determination to predict brand purchase intention in Kenya. This result is expected and supports prior researches that these studies agree with AC Nielson, 2005 that notion of higher quality associated with brand products is increasingly being challenged. In today environment people are looking not only at quality product or service, they also need product that has positive, memorable experiences. Emotional value is acquired when a product/services arouses feelings or effective states (Sheth et al., 1991); perceived brand quality is a result of consumers' subjective judgment on a product.

Brand Prestige was also found to be significant to predict brand purchase intention in Kenya. The finding provides evidence to support prior studies Findings from van Kempen (2004) showed that the post graduate students were willing to sacrifice basics, like food, in order to obtain the status brand. Essentially, post graduate students may perceive status as important to gain recognition (Goldsmith, Clark and Zboja, 2007). Brand prestige can represent the relatively high status of product positioning associated with a brand (Steenkamp, Batra, \& Alden, 2003; Truong, McColl, \&Kitchen, 2009). An inherent, unique know - how, which concerns a specific attribute or the overall quality and performance of the product, is the key criterion for a brand to be judged prestigious (e.g., Dubois \& Czellar, 2002). In other words, consumption of prestige brands may vary according to the susceptibility to others (Vigneron \& Johnson, 1999). Wong and Zhou (2005) found that perceived brand prestige has a greater effect on purchase intention when the product category is high social display value (Zhou \& Wong, 2005). 


\subsection{Implications}

Perceived quality is the recognition of product quality, which has an influence on consumer purchasing behavior. This recognition is the formed judgment or evaluation by consumers during the acquisition, receiving and processing of information related to products. In making judgments, consumers usually give first priority to the product quality. Therefore, perceived quality has a great influence on consumer purchasing behavior, and whether it is good or not will have a direct influence on the purchasing decisions and perceived value by consumers. Purchasing will be influenced by the perceived quality and that perceived quality is proportional to the perceived value of products. In other words, the higher the consumers' awareness of perceived quality, the higher the perceived value, and this promotes the willingness of consumers to purchase. Therefore, it is proved that perceived quality has a significant influence on consumer purchasing behavior.

Consumers prefer the highest status mobile phone brand even if a consumer is aware that a higher mobile phone brand and lower status mobile phone brand come from the same factory. Also, consumers may perceive status as important to gain recognition because the status of the mobile phone brand is associated with using better materials or lower variability of quality. Therefore, a high-status brand may have a high price, higher standards of excellence, superior quality, snob appeal, luxurious features and exclusively, being associated with the wealthy, successful or elite. The overall value of a brand has been said to be influenced the relative strength of a consumer's positive feelings toward the brand. The value of the brand is linked to the intensity of the feelings aroused by the brand, and this is important to marketers because the value of the brand is not based on a brand's ubiquity, visibility, or functionality.

\section{References}

- $\quad$ Aaker, A.D., Kumar, V., and Day, S.G. (2007). Marketing Research (9th ed). USA: Wiley and Sons.

- Ajzen, I. (1991). The Theory of Planned Behaviour, Organizational Behaviour and Human Processes, 50: 179211.

- Batra, R. and M. B. Holbrook 1990. Developing a Typology of Affective Responses to Advertising. Psychology and Marketing 7(1), 11-25.

- Dodds, W. B., Monroe, K. B., \& Grewal, D. (1991). Effect of price, brand and store information on buyers' product evaluations. Journal of Marketing Research, 28(3), 307-319.

- Edell, J. A. and M. C. Burke 1987. The Power of Feelings in Understanding Advertising Effects. Journal of Consumer Research, Journal of Consumer Research, Inc. 14, 21-434.

- Field, A. (2005), Discovering Statistics Using SPSS, 2nd ed., Sage, London.

- Fishbein, M., and Ajzen, I. (1975). Belief, Attitude, Intention, and Behavior: An Introduction to Theory and Research. Reading, MA: Addison-Wesley.

- Garver, M.S. and Mentzer, J.T. (1999), "Logistics research method: employing structural equation modeling to test for construct validity", Journal of Business Logistics, Vol. 20 No. 1, pp. 33-58.

- Garvin, D.A. (1983). Quality on the Line. Harvard Business Review, pp. 65-75.

- Goldsmith, R. E., R. Clark and J. Zboja 2007. Status Consumption and Role-Relaxed Consumption: A Tale of Two Retail Consumers. Journal of Retailing and Consumer Services 14, 45-59.

- Hair, Jr., J. F., Black, W. C., Babin, B. J., Anderson, R. E., and Tatham, R. L. (2006). Multivariate Data Analysis (6th ed.). Upper Saddle River, NJ: Pearson Prentice Hall.

- Hill, R. C., Griffiths, W. E. and Judge, G. G. (2001). Undergraduate econometrics (2nd ed.). New York: John Wiley and Sons.

- Jaccard, J., and Turrisi, R. (2003). Interaction Effects in Multiple Regression (2nd Ed). Thousand Oaks, CA: Sage Publications.

- Keller, K.L. (1998) Strategic Brand Management: Building, Measuring, and Managing Brand Equity, Prentice-Hall: Upper Saddle River, NJ.

- Kumar, R. (2005). Research Methodology: A Step-by-step Guide for Beginners (2nd ed.). Melbourne, Australia: Longman.

- Langer, J. (1997). What Consumers Wish Brand Mangers Knew. Journal of Advertising Research 37(6), 6065. 
- $\quad$ Lassar, W. M., Manolis, C., and Winsor, R. D. (2000). Service Quality Perspectives and Satisfaction in Private Banking. Journal of Service Marketing, 14 (3), pp. 244-271.

- Luarn, P. and Lin, H.H. (2005), "Toward an understanding of the behavioral intention to use mobile banking", Computer in Human Behaviour, Vol. 21 No. 6, pp. 873-91.

- McGoldrick, P. J. 1984. Grocery Generics - An Extension of the Private Label Concept. European Journal of Marketing 18(1), 5-25.

- Neter, J., Wasserman, W., and Kutner, M. H. (1985). Applied linear statistical models:Regression, Analysis of variance, and experimental designs. Homewood, IL: Richard D. Irwin.

- Nunnlly J.C and Bernstein, I.H (1994). Psychometric Theory, $3^{\text {rd }}$ Edition. New York: McGraw. Hall Inc.

- Nunnally, J. (1978), Psychometric Theory, McGraw-Hill, New York, NY.

- O'Shaughnessy, J. and N. J. O'Shaughnessy 2002. Marketing, the Consumer Society and Hedonism. European Journal of Marketing 36(5/6), 524-547.

- Paurav Shukla. (2009), "Impact of contextual factors, brand loyalty and brand switching on purchase decisions", Journal of Consumer Marketing, Vol. 26 No.5, pp. 348-357.

- Teng, Laroche and Huihuang. (2007), "The effects of multiple-ads and multiple-brands on consumer attitude and purchase behavior", Journal of Consumer Marketing, Vol. 24/1, pp. 27-35

- Terrell, G.W., 2002. Social class influences on purchase evaluation criteria. J. Consum. Mark., 19(3): 46-59.

- Thompson, C. J., A. Rindfleisch and Z. Arsel 2006. Emotional Branding and the Strategic Value of the Doppelganger Brand Image. Journal of Marketing 70(1), 50-64.

- Vigneron, F. and L. W. Johnson 2004. Measuring Perceptions of Brand Luxury. Journal of Brand Management, Henry Stewart Publications. 11, 484-506.

- Wang, S. and Barnes, S. (2007), "Exploring the acceptance of mobile auctions in China", Proceedings of the Sixth International Conference on the Management of Mobile Business, Toronto, Canada.

- Wang, W.Q. and Benbasat, I. (2007), "Recommendation agents for electronic commerce: effect of explanation facilities on trusting beliefs", Journal of Management Information System, Vol. 23 No. 4, pp. 217-46.

- Wong, C.C. and Hiew, P.L. (2005), "Diffusion of mobile entertainment in Malaysia: drivers and barriers", Enformatika, Vol. 5, pp. 263-6.

- Zeithaml, V. A. (1988), Consumer perceptions of price, quality and value: a means-end model and synthesis of evidence. Journal of Marketing, 52, 2-22. 